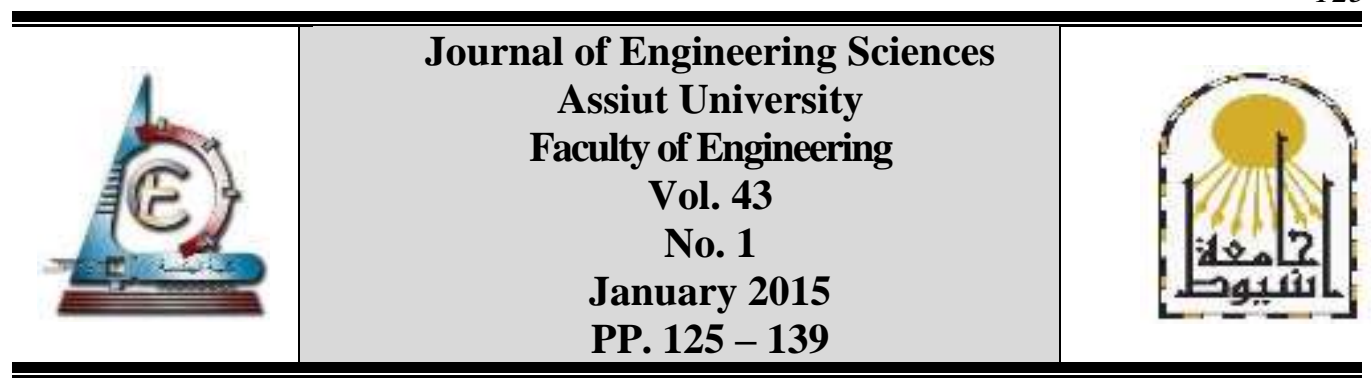

\title{
FORMING A CONSTRUCTIVISM DESIGN STUDIO: SIMULATION OF REAL-LIFE ARCHITECTURE EXPERIENCE ON AN EXPERIMENTAL YOUTH WORKSHOP IN EGYPT
}

\author{
Khodeir M. Laila \\ Department of Architecture, Faculty of Engineering, Ain Shams University, Cairo, Egypt
}

(Received 6 January 2015; Revised 26 January 2015; Accepted 10 February 2015)

\begin{abstract}
This paper aims at presenting the lessons learned during the planning, initiation and execution of an experimental youth workshop named ""How to make your own Dream House?". The workshop took place in the Faculty of Engineering at Ain Shams University, Egypt as a part of a department of Architecture activity week in the year 2013. This workshop simulated the real-life architecture experience to two different age groups of young learners: kids from 7-10 years old and teens from 11-17 years old. The targeted youth audience represented a population not likely to consider the study of architecture and that was a relevant factor in the workshop creation. To achieve the aim of the workshop the constructivism design studio environment was applied as a major component for learning architecture. The detected findings of this paper could help those involve in teaching architecture to either young learners or junior students of architecture in stimulating collaborative architecture learning environments. Meanwhile, the paper offers relevant methods of introducing future generations to the study of architecture.
\end{abstract}

Keywords: Architecture Experience- Young Learners-Constructivism Design StudioExperimental workshop

\section{Introduction}

Learning is not an activity that occurs only in the mind, but is also an activity that happens in a social and cultural context. When learning is situated in real-world contexts, what is learned is better remembered, and problem-solving skills become linked to situations similar to those likely to be used, thus facilitating transfer. [1] In general, the effective learning environments focus on students' understanding and application of knowledge. [2] This can be done by asking students to participate in projects, solve complex problems, design and execute experiments, think about their ideas, listen to the ideas of others and, in general, assume control of their learning. Thus engaging students of architecture with the teaching staff in active learning processes is crucial. [1]

Architectural education has a very unique nature amongst many other educational sciences. The architectural student is confronted with various factors that impose different 
design solutions; the analysis of these factors enables them to make different related design decisions. On the other hand, the study of architecture comprises the implementation of theories and rules extracted from narrative lectures and tutorials in different subjects, such as structural engineering, environmental control, theories of architecture and urban design. In Architecture education, moving from traditional classrooms to the "design studio" varies greatly from pedagogical, sociological, ideological epistemological perceptions. [3]

The role of the instructor focuses on couching the student during their analysis, proposing design alternatives and finalizing their project. [4] It is therefore important to provide students with culturally meaningful and purposeful tasks that make deliberate use of the physical and social context. The main challenge that might face the instructor in his journey to achieve this learning environment lies in how he could give the students enough motivation to become an active participant in the learning environment.

Workshops are important events in the studio. These short, intensive studio teaching sessions involve following a task that relates to a particular stage in a given project. This is carefully focused and designed to equip students with a new skill or way of working. The experimental youth workshop, entitled: "How to make your own Dream House?" which took place in the Faculty of Engineering at Ain Shams University, Egypt as a part of a department of Architecture activity week in the year 2013, aimed at creating a Simulation of real-life architecture experience, through which the organizers and the participants of the workshop can learn. In other words, to allow all participants to understand the essence of the work of an architect by passing through different phases of design stating from briefing, concept generation, 2D drafting, 3D modelling and finally understanding the urban context. To achieve the aim of the workshop the constructivism design studio environment was applied as a major component for learning architecture.

The main theme of the workshop was: "How to make your own Dream House??" it was intended for two different age groups: kids from 7-10 years old and teens from 11-17 years old. The issue was that the targeted youth audience formed a population not likely to consider the study of architecture and that was a relevant factor in the workshop creation. The challenge formed was namely "teaching architecture to either young learners or junior students of architecture in stimulating collaborative architecture learning environments". Such types of learning environments were selected based on the concept that the more you practice, the better you get. The act of learning by doing gives instant feedback in terms of the visual and physical result and this allows young learners to do it better the next time. "

\subsection{The main objective}

This paper aims at offering a description of the simulation of real-life architecture experience on an experimental youth workshop. This included the simulation of the studio environment that is common for learning architecture.

The objective of this paper is twofold;

First: How the analyses and lessons learnt from this case study could be used in teaching architecture to young learners.

Second: How to allow young learners to have maximum understanding of the concepts of architecture. 


\section{Methodology}

The population for this case study included about 40 young learner who participated in the workshop, a stuff member (the main coordinator of the workshop), about 9 teaching assistants( TAs), a post-graduate architect who works on the theme of teaching architecture to young kids, and more than 20 under-graduate students from different educational years.

The objective of this paper is achieved through the analysis of the case-study workshop. The analysis is done on four main features as follows:

At first, the structure of the Simulation experience is analyzed, where its main dimensions were revealed.

Secondly, the phases of creating the experimental workshop are discussed in detail.

Thirdly, the strategies that were implemented to develop the simulation experience were explained. These included teaching methods, motivation tools, implementation and praising strategies. Furthermore, the end-products of participants as a follow-up of their personal development and their level of satisfaction were assessed.

Finally, the level of understanding of Architectural real- life experience achieved throughout the phases of the workshop was detected and accessed.

\section{Analysis of the Experimental Workshop}

An analysis of the experimental workshop is introduced in the coming part of the paper, where the type of design studio, teaching methods applied and different aspects of the simulation experience are emphasized.

\subsection{Moving from Traditional Design Studios to Constructivism Design Studio}

According to (BOYER \& Mitgy 1996) architecture studio is defined as "a way of thinking during which the many elements, possibilities and constraints of architecture knowledge are integrated". [5] Long ago, design studio served as the core of architecture education, which focused on learning by doing. However, design studio could sometimes be misinterpreted when it turns into a simple narrative process. In this case the professor takes the role of an instructor and tells the student what to do; they just have to follow him/her. Olotuah (2012) highlighted that traditional design-studios do not provide the students with skills needed to make building drawings for approval or even manage or supervise a simple building project. This has driven scientists to investigate the studio teaching/learning actions to incorporate "constructivism" view to traditional design studio. [6]

The young learners' workshop was based on implementing the concepts raised in three different researches that took place in different time phases.

The first one is Schon 1887 who generated the concept of "reflection in action ". This concept was implemented in the experimental workshop where behavior of participants changed to address new conditions related to simulating the life of an architect. Acting was achieved through imitating designers in the concept generation, drafting and 3-D modelling. The second research was done by (kert 2009) where he defined the main characteristics of the constructivism design studio as follows: 
Khodeir M. Laila, forming a constructivism design studio: simulation of real-life architecture...

- Focusing on the design process.

- Developing new skills and tools for learning procedures.

- Using Multimedia applications.

- Encouraging Role Playing, virtual reality and simulation.[7]

These concepts and procedures were also used in the workshop in order to form an effective constructivism design studio.

Finally, the main themes that differentiate constructivism studio from traditional design studio raised by Eigbeonan, A. (2013) were taken as a road map for creating the experimental young learners workshop. This includes achieving collaboration, integration, adaptability and motivation. [8]

Collaboration was basically achieved by involving different types of stakeholders, including professors, Teaching assistants and architecture students from different years. All Participants integrated together in order to secure a culture of continuous improvement. Adaptability was fulfilled in the theme of the workshop itself, "Real Life architecture experience", while Motivation strategies were varied throughout the workshop.

\subsection{Factors Affecting Classification of Young Learners}

On the contrary of the traditional design studio the constructivism studio implemented in this workshop was structured as a "spread studio", where both young learners and junior architecture students came from different academic years. Several factors affected the classification of the workshop participants, including:

a- The individual progress of each participant: where attention was given to developing appropriate tasks to each young learner. They were subjected to the challenge of making their dream house, meanwhile they were encouraged to express it in any means they want (plan, elevation, isometric). In addition, the organizing members were encouraged to understand the strengths and weaknesses of each participant during the starting phases and to take them into consideration while working with them.

b- The cultural differences, which affect the students' comfort level in working collaboratively instead of individually. This was handled through the strategies of breaking the ice (discussed later) and through designing the required tasks in both ways, individual and collaborative.

c- The participants' conceptions of what it means to be intelligent: as participants who want to look good rather than take the risk of making mistakes are likely to give up when tasks become difficult. [2] This issue was handled through adding competition in the final phase of the workshop, to encourage the participants to keep on the good work.

\subsection{Type of design studio}

There are different types of design studio applications [7], the type that was implemented in this workshop was "the constant jury". In this system of application 3 to 4 instructors normally manage the studio operations, but this number was doubled throughout the workshop to ensure full guidance to young learners. Both the young learners and the organizers were from different academic levels. This system encouraged collaboration, participation and discussion concerning the theme of the workshop. 
Figure (1) shows a schematic shape for the type of studio applied and a number of shots showing how it was applied in the actual workshop.
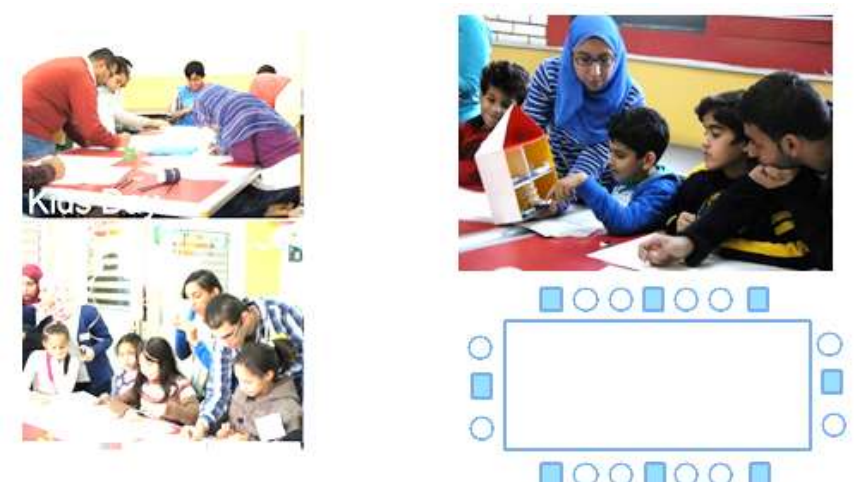

Fig. 1. The constant jury design studio and how applied through the workshop Source: Author and [7] Kurt, S. (2009)

The simulation of real-life architecture environment through the created constructivism studio was achieved through creating an overall ambience that called for collaborative, cooperative, learning communities and discovery. This ambiance was a resultant of three main constituents: the physical environment, the social environment and the time-based environment.

\subsubsection{Simulation of the real-life architecture physical environment}

The physical environment of the workshop included setting the ambience in a way that makes it simulates the traditional design studio being open, tolerant, comfortable, and safe. The objective of setting such climate was to achieve significant learning where all participants can interact, meanwhile simulates real-life architecture studios, Figure (2).

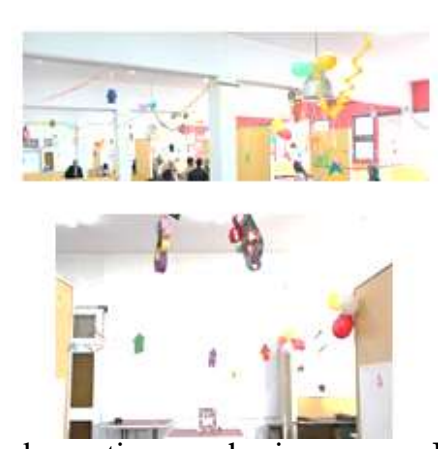

Fig. (2.a.) Interior decoration emphasizes the tolerant, open atmosphere.

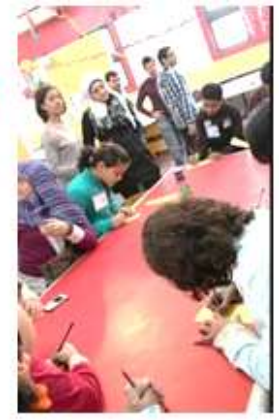

Fig. (2. B.) Choosing colorful open workspace to create a comfortable ambience.

Fig. 2. The ambience created inside the workshop - Source: Author

The space was arranged in such a way as to encourage the interaction between the participants and the organizers (fig. 2-a), using stools and sitting in groups, each including about 5-7 kids/teens. The space chosen for holding the workshop was the final year design studio in the department of architecture; the studio furniture includes large red-colored tables, (fig. 2-b). The materials, including drawing tools (pencils, different color types, 
transparent sheets, cardboard, brushes, rolling sponges), modeling tools (foam sheets, colored paper, toothpicks, straws, play dough, etc.) were allocated on a central table in the studio were the organizers handle them to each group upon need.

\subsubsection{The simulation of real-life architecture social environment}

Creating the social environment was achieved through applying the workshop goals including safety regulations, where young learners were not allowed to use any tools or equipment (such as cutters, wax guns, etc.) that might cause injuries. Instead, the organizing teams were responsible for any process that involves the usage of sharp or electric-equipped tools.

The workshop goals also included achieving respect among all participants and organising groups. Resposibilities of each work group were clearly identified. Meanwhile, complete cooperation was sustained between all groups.

\subsubsection{Simulation of the real-life architecture time- based environment}

Creating the time-based environment depended on three main factors: the first was the workshop timetable, including the tasks to be achieved within the overall time of the event; the second was the kids/teens human needs for rest and snack time recreational activities, figure (3-a); and finally, appreciating individual differences among participants. The last factor was handled through adding extra activities that suit different age groups (including coloring sheets, origami art work...etc.), figure (3- b).

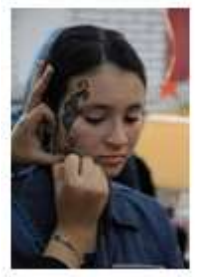

Fig. (3. A.) Face painting for young learners in recreational time

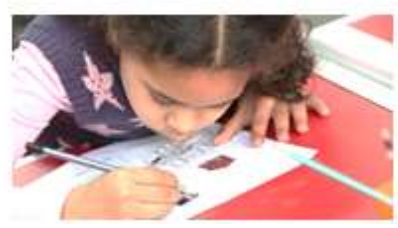

Fig. (3. b.) Coloring worksheets on the theme "my dream house"

Fig. 3. Extra activities during workshop time - Source: Author

\subsection{Teaching methods in experimental workshop}

The process of how the content of the workshop was actually delivered was based on simulating real-life situations through which all participants can learn. Teaching methods that were implied in the workshop were actually a blended number of methods that oriented young learners regarding their different age groups, individual differences and cultural backgrounds. The participants of the workshop were subjected to real-life situations, in different ways.

\subsubsection{Implemented teaching methods in planning phase}

- Role playing: Involving them in the promotion for the workshop: a movie was made by the instructors of the organizing committee to promote the workshop. It involved the participation of one of the teens who participated in the workshop. 


\section{- Making an Experimental Workshop}

In order to design effective environments for learning, the influence of the kids/teens perceptions of the learning environment on their learning strategies should be considered. [9] In order to achieve that, the coordinator needs to know how kids/teens can learn architecture, and how specific architectural concepts are acquired, in addition to checking how the kids/teens would accept the theme of the workshop and the difficulties they might encounter during making their dream houses. The experiment was done on a number of young learners that were equivalent to $10 \%$ of the actual number of attendants. The conclusions of these simulations have led to the following:

Firstly: the point of interest for the kids obviously varied from that of teens. Kids focused on coloring; they could easily understand the concept of plan and section through cutting colorful fruits and drawing what they saw. Teens could be encouraged to draw plans and sections of a real 3-d open model.

Secondly: the ability and degree of concentration of kids on rules was weak, which suggested giving them shorter tasks that took less time (coloring, making parts of a house, furnishing the house). In addition, kids needed extra activities, like making origami shapes and forming play dough.

Teens, on the other hand, could be introduced to the concept of drawing on transparent sheets, where they could modify their drawing using the concept of layering.

Thirdly: the means of expression: when the kids were asked to describe their dream house they tried to describe it in terms of the vocabulary of shapes they know, for example, a cube, star, diamond; while the teens concentrated on the functions inside the house and the place it will be located in (the surrounding environment).

Finally: kids/teens participating in that experiment were allowed to criticize the design of their own houses which formed a good opportunity for them to interact. The workshop made use of the results of that experiment, especially when setting the interactive presentations for both target groups by asking them questions like: "what do you like most about your house?", "where do you prefer to live?" and "what is the worst thing you want to change in it?"

\subsubsection{Implemented teaching methods in initiation phase}

The initiation or starting phase of the experimental workshop included using a number of teaching methods in each session as follows:

a. The "breaking the ice" approach aimed at creating an effective interaction between the organizers and the young learners at the beginning of the workshop. The young learners were introduced to each other and to the organizing team in an indirect way. Meanwhile, there was a need to differentiate between breaking the ice of young kids from that of teens, so two different strategies were adopted for the two target groups.

The first strategy involved using the name grid for kids, where young people were divided into groups of four. Each group used paper and pens. They were asked to draw a grid on which they write their forenames. Each team was given five to ten minutes to write down as many words (three letters or more) that they can make only using the letters in 
their names. When time is up each team summed up their score by adding a point for every word they got.

The second strategy aimed at socializing with the teens through drawing a self-portrait. The students drew themselves then their drawings were hanged up for the whole class to see. Then they tried to guess who the artists were for each picture.

\section{$b$-Motivation Session (presentations, storytelling, movies)}

The motivation session aimed at transferring knowledge to young learners in an indirect way so as to motivate them to start thinking about what their dream house could look like in the following session.

- physical exercises were implemented where young learners could express the action of each architectural element through their body, as shown in fig (4),[10]

- The story-telling approach was mainly used with the kids from 7-10 years old. This method has a long history of use in structuring, organizing and communicating human experience. It had a significant impact on the way the kids understood and used to come to conclusions, [11]. The role of the architect was exposed to kids in an indirect way through a story-telling approach. They were told a story about a little kid who wanted to make a shelter to his cat, figure (5).

- Interaction and discussion: young learners were asked to interact with a movie made from parts of different amusing cartoons that included different forms and types of houses, add their opinions about the houses they saw and even suggest solutions to some problems. (For example: "how can we ever get inside an apartment house without the existence of stairs?")

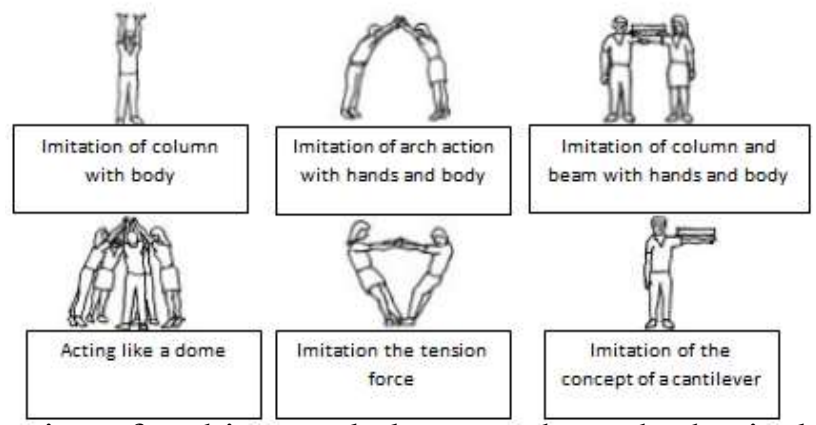

Fig. 4. The action of architectural elements through physical exercises [10]

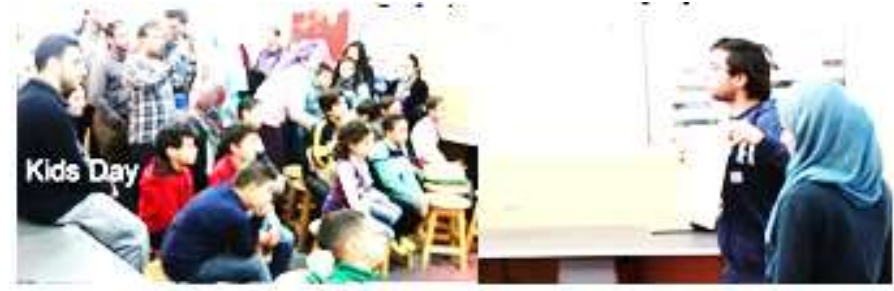

Fig. 5. The story-telling to let young kids understand the role of an architect in the workshop. source: Author 
d- Demonstrations: the instructors showed young learners the concept of the plan and the section through cutting peppers and horizontally and vertically, then they were introduced to 3-d models of simple pitched house to show them how the house could be in plan and in section, Figure (6).
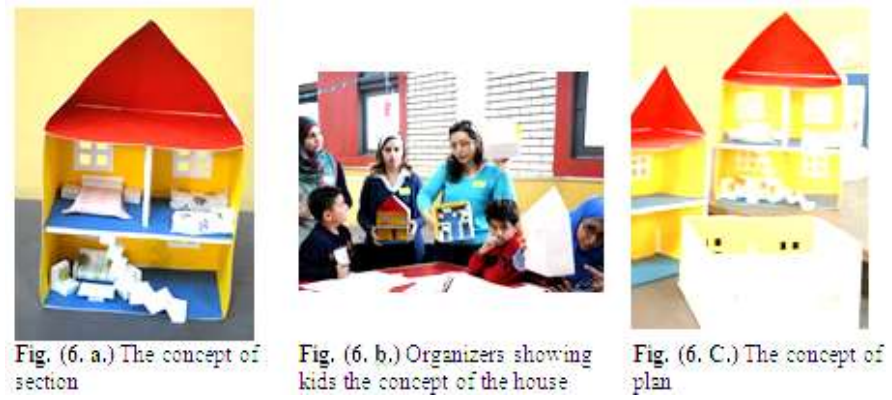

Fig. 6. Models to illustrate the concept of a house to kids 7-10 - Source: Author

\subsubsection{Implemented teaching methods in implementation phase}

- During the implementation phase a Design Problem named "How to design your own dream house" was given to young learners with no specific solution. Instead they were given limitation functional, technical or contextual.

a. The functional limitations were related to the nature of the project "house" and the spaces that should be provided inside it.

b. The technical limitations were mainly considered with the type of materials to be used in model making. A number of modeling materials was chosen according to their availability, ease of use relative to each age-group and their modeling capabilities. The materials selected included play dough, foam sheets, pre-cut foam units, linear elements (toothpicks and straws), folded paper house-models and plain square sheets for origami work. Figure (7) shows different samples set by the team for different types of materials.

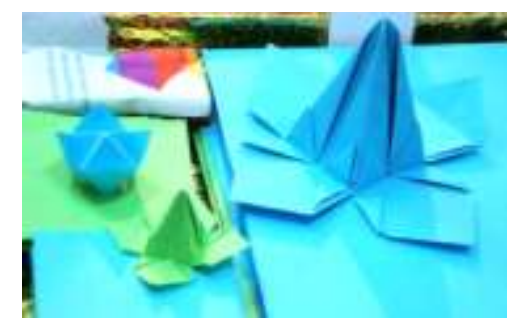

Fig. 7. Samples of the modeling units used inside the workshop - Source: Author

- Finally the contextual limitations were represented on a large 3-D map, where each learner should insert his house model in it in a specific location (overlooking main street, wide garden ...,etc.). The designed map could stand all the 3 -d models of the young learners relative to the scale of the required model. The map included main roads, secondary roads, gates for the neighborhood, points of attraction and some landscape elements, Figure (8). 


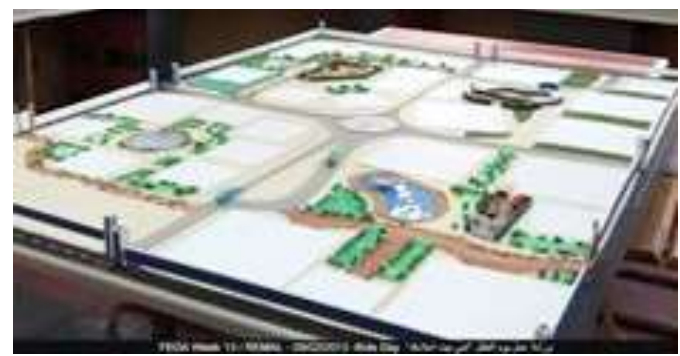

Fig. 8. The contextual limitations of the design problem illustrated through a map of a virtual site in the workshop - Source: Author

\subsubsection{Implemented teaching methods in appraisal and praising}

All the active young learners were able to develop their work and were praised through offering them certificates of honor in addition to a bracelet that had the national flag on it. The young learners were also given a medal made by laser cutter that has the logo of the workshop by the end of the day, figure (9).In addition they were allowed to collect their end products one week after the workshop.
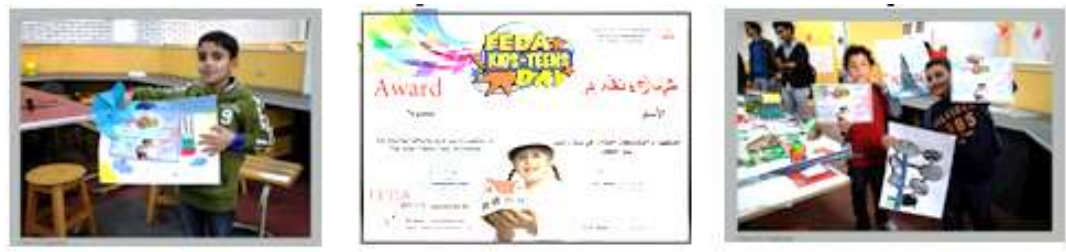

Fig. 9. Honoring the participants at the end of the day as a method of appraisal Source: Author

\section{Assessment of the end products}

As in any constructivism studio the assessment process of end- products focused on the design process. Assessment Reviews happen at various stages of the workshop. These took the form of either informal pin-ups or formal interim and final reviews. However, the most common is for students to pin up their work, display their models and present their work verbally to a panel of reviewers and students. It is important to plan a convincing verbal presentation in order to communicate the project fully in the time allocated.

Young learners were supposed to perform reflections on actions. The developed products were recognized as the representative of the design process. The steps the young learners have passed through from the concept generation to the model making were monitored.

The end products of young learners in the first session of the workshop took the form of 2-d drawings were they used colors to present their work on an A3 white sheet, figure (10). Their illustrated dream houses were hanged on the back walls in order to be seen by all participants, figure (10-a). 
In the following session, after the workshop coordinator and teaching assistants analyzed their work and categorized it, the young learners were offered suitable materials to make their 2-d house come true through modeling. They all presented different ideas whether in form (star house, boat house, figure (10-b), origami house, (figure 10-c), pitched or domed house, figure (10-d) or in the surrounding environment (house in space, on an island, inside the sea) for their dream houses.

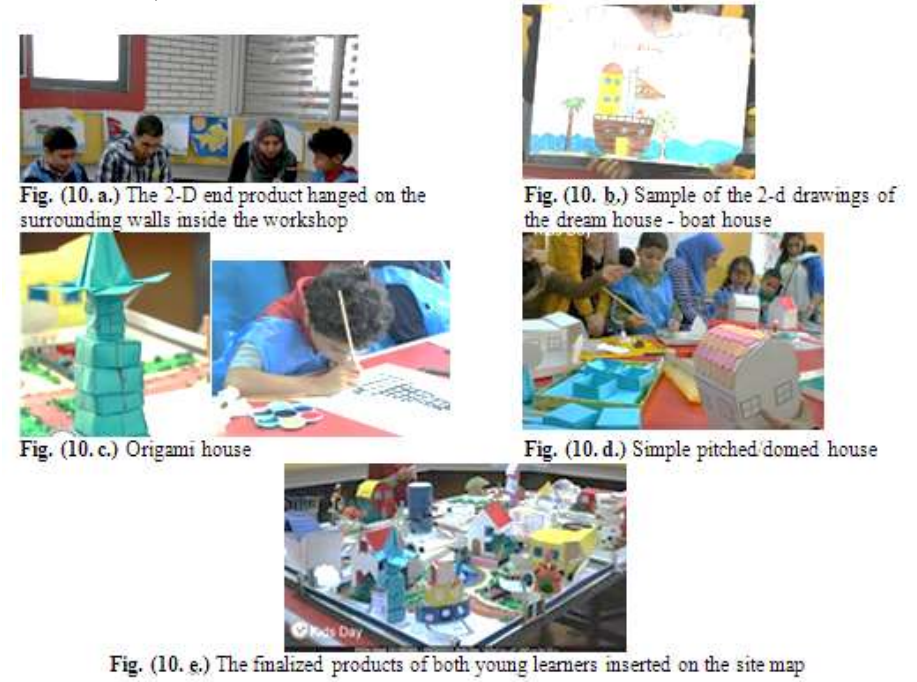

Fig. 10. The 3-D end-product of the workshop - Source: Author

\section{Generic feedback (lessons learned)}

The generic feedback is about the self-correction and evaluation of the effectiveness of the experimental workshop. The feedback data was gathered from both the workshop organizers and the kids/teens who participated in it. The latter were allowed to express their impressions either verbally to the coordinator of the workshop or by writing them on a large white sheet inside the workshop space. The organizers provided their feedback one day after the end of the workshop, they were asked to criticize the day openly on the internet group of the event.

\subsection{The young learners feedback}

The participation of some of the kids/teens in some of the activities related to the preparation of the workshop, like acting in the promotion video of the workshop, gave the participating kids/teens a sense of sharing and emphasized interaction between them and the other members; in other words, they felt that they were part of the event. Their degree of satisfaction was detected through their own impressions about the day. Most of the kids, by the end of the day, asked: "When is the next workshop?", while some others helped the organizing team in cleaning up the place of the workshop, which showed great feeling of belonging to the place.

\subsection{The efficiency of constructivism design studio}

This paper suggests that throughout the phases of this experimental workshop, principles of making an effective constructivism studio (coordination, collaboration, and learning communities) were followed; meanwhile young learners were subjected to a 
Khodeir M. Laila, forming a constructivism design studio: simulation of real-life architecture...

simulation of a real-life architect. Table (1) shows degree of collaboration between young learners and their instructors staff members ( professors and teaching assistants (TAs )and instructors from senior or junior architecture students throughout the phases of the workshop and degree of impact of each stakeholder; it also offers an analysis of the detailed roles performed by each stakeholder during the collaboration process. The degree of impact of each stakeholder role in each phase of implementation of the workshop is coded as follows: $\mathrm{H}$ (high degree), M (moderate degree) and L (low degree).

Table 1.

The level of interaction (Integration) throughout the phases of the workshop and degree of impact (Collaboration) of each stakeholder

\begin{tabular}{|c|c|c|c|c|c|c|c|}
\hline \multirow{2}{*}{\multicolumn{2}{|c|}{ Phase of implementation }} & \multicolumn{6}{|c|}{ Stakeholders involved } \\
\hline & & \multicolumn{2}{|c|}{ Staff members } & \multicolumn{2}{|c|}{ students } & \multicolumn{2}{|c|}{ young Learners } \\
\hline General & Sub-phase & Prof. & TAs & $\begin{array}{l}\text { Juni } \\
\text { ors }\end{array}$ & $\begin{array}{l}\text { Sen } \\
\text { iors }\end{array}$ & kids & Teens \\
\hline \multirow[t]{2}{*}{ Planning } & $\begin{array}{l}\text { Classification of } \\
\text { participants }\end{array}$ & $\mathrm{H}$ & $\mathrm{L}$ & & & & \\
\hline & Delegation & $\mathrm{H}$ & $\mathrm{M}$ & $\mathrm{L}$ & $\mathrm{M}$ & & \\
\hline \multirow{8}{*}{ 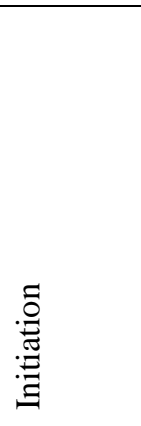 } & $\begin{array}{l}\text { Selection of } \\
\text { workshop theme }\end{array}$ & $\mathrm{H}$ & $\mathrm{M}$ & & $\mathrm{M}$ & & \\
\hline & $\begin{array}{l}\text { Creating an internet } \\
\text { group }\end{array}$ & $\mathrm{H}$ & $\mathrm{L}$ & $\mathrm{L}$ & $\mathrm{L}$ & & \\
\hline & \multirow{6}{*}{$\begin{array}{l}\text { Forming work- } \\
\text { groups }\end{array}$} & $\mathrm{M}$ & $\mathrm{L}$ & $\mathrm{L}$ & $\mathrm{M}$ & & $\mathrm{L}$ \\
\hline & & $\mathrm{L}$ & & $\mathrm{H}$ & $\mathrm{M}$ & & \\
\hline & & $\mathrm{L}$ & $\mathrm{M}$ & $\mathrm{H}$ & $\mathrm{M}$ & & \\
\hline & & $\mathrm{L}$ & $\mathrm{H}$ & & & & $\mathrm{M}$ \\
\hline & & $\mathrm{M}$ & $\mathrm{M}$ & $\mathrm{L}$ & $\mathrm{H}$ & & \\
\hline & & $\mathrm{H}$ & $\mathrm{H}$ & $\mathrm{H}$ & $\mathrm{H}$ & & \\
\hline \multirow{9}{*}{ 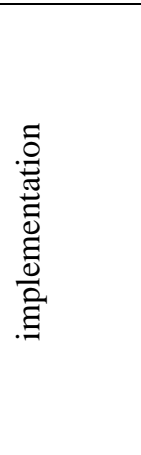 } & $\begin{array}{l}\text { Making a virtual } \\
\text { workshop }\end{array}$ & $\mathrm{L}$ & & $\mathrm{H}$ & & $\mathrm{H}$ & $\mathrm{H}$ \\
\hline & \multirow[t]{2}{*}{ Breaking the ice } & $\mathrm{L}$ & $\mathrm{L}$ & $\mathrm{H}$ & $\mathrm{L}$ & $\begin{array}{l}\mathrm{M} \\
\mathrm{L}\end{array}$ & \\
\hline & & $\mathrm{L}$ & $\mathrm{M}$ & & $\mathrm{M}$ & & $\mathrm{H}$ \\
\hline & \multirow[t]{6}{*}{ Motivation } & $\mathrm{L}$ & $\mathrm{L}$ & $\mathrm{H}$ & $\mathrm{L}$ & $\mathrm{H}$ & \\
\hline & & $\mathrm{L}$ & & & $\mathrm{H}$ & $\mathrm{M}$ & \\
\hline & & $\mathrm{L}$ & $\mathrm{H}$ & & $\mathrm{H}$ & $\mathrm{M}$ & $\mathrm{M}$ \\
\hline & & $\mathrm{L}$ & $\mathrm{L}$ & $\mathrm{H}$ & $\mathrm{H}$ & $\mathrm{L}$ & $\mathrm{L}$ \\
\hline & & $\mathrm{M}$ & $\mathrm{M}$ & $\mathrm{M}$ & $\mathrm{M}$ & $\mathrm{H}$ & $\mathrm{H}$ \\
\hline & & $\mathrm{L}$ & & $\mathrm{M}$ & $\mathrm{H}$ & $\mathrm{M}$ & $\mathrm{M}$ \\
\hline \multirow{3}{*}{$\begin{array}{l}\bar{\Xi} \\
\dot{0} \\
\dot{D} \\
0 \\
0\end{array}$} & $\begin{array}{l}\text { Evaluation of 2-d } \\
\text { products }\end{array}$ & $\mathrm{H}$ & $\mathrm{H}$ & & & & \\
\hline & $\begin{array}{l}\text { Production of 3-d } \\
\text { models }\end{array}$ & $\mathrm{L}$ & $\mathrm{M}$ & $\mathrm{M}$ & $\mathrm{M}$ & $\mathrm{H}$ & $\mathrm{H}$ \\
\hline & $\begin{array}{l}\text { Honouring the } \\
\text { participants }\end{array}$ & $\mathrm{M}$ & $\mathrm{M}$ & $\mathrm{H}$ & $\mathrm{M}$ & & \\
\hline
\end{tabular}




\section{Conclusions}

- The workshop was able to create collaboration, coordination and learning community throughout all its phases, where the highest level of collaboration achieved was evident during the implementation phase (85\% of the stakeholders got involved). While the level of interaction in the rest of the phases was of medium range (50-65\% of the stakeholders got involved).

- Participating in the workshop was based on creating a communication channel for student to student, student to teacher (staff members) and organisers (students and staff members) to kids/teens collaboration. The degree of impact of the organisers was higher (relative to participants) at the beginning phases of the workshop, while that of the participants' impact was higher during the implementation and the closing phases, Figure (11).

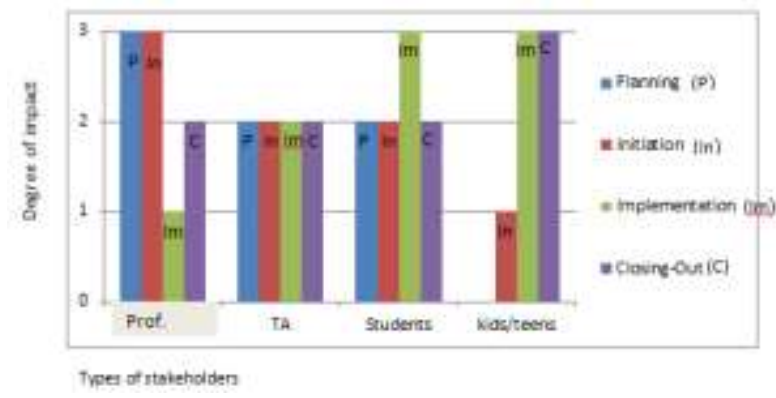

Fig. 11. The relationship between the stakeholders and their degree of impact throughout the phases of the workshop.

- The added value for each participant brought by that form of learning, together with the knowledge about the issue of the workshop, was involved in benefiting both personal and institutional aspects.

\section{Recommendations}

The findings of this paper could help those involved in teaching architecture to either young learners or junior students of architecture in stimulating collaborative architecture learning environments. Meanwhile, the paper offers relevant methods of introducing future generations of in Egypt to the study of architecture.

The paper concludes that forming a constructivism design- studio is correlated with achieving better integration, more motivation and finally can provide young learners who are interested in architecture with a creative learning experience.

This paper recommends applying the teaching methods that were implemented throughout the young learners' workshop, in order to create an effective constructivism design- studio and a successful learning environment where all participating groups can collaborate and benefit. 


\section{REFERENCES}

[1] Stella V., Christos I., et al - (2001), designing learning environments to promote conceptual change in science - Elsevier -Learning and Instruction, vol. 11, pp. (381-419).

[2] R. Abdul-Magid \& T. Sherman - (2005), Effective Learning Environments -Higher Education DV Workshop - King Abdul Aziz University Jeddah, KSA- January 30 February 1.

[3] Sagun, A, Demirkan, H and Go“" ktepe, M, (2001), 'A framework for the design studio in web-based education' Journal of Art and Design Education Vol 20 No 3 , pp. 332-342

[4] Riklef R., Rainer B. Westfglische W. (1995), Implicit Psychological Concepts in Architects' Knowledge - How Large IS a large room? Learning and Instruction, Elsevier Science Ltd, Vol. 5, pp. 337-355.

[5] Boyer, E. L. \& Mitgang, L. D. (1996). Building community: A new future for architectural education and practice. Princeton, NJ: The Carnegie Foundation for the Advancement of Teaching.

[6] Schon, D.A. (1987). Educating the Reflective Practitioner. San Francisco: Jossey-Bass.

[7] Kurt, S. -(2009), An analytic study on the traditional studio environments and the use of the constructivism studio in the architectural design education- Procedia Social and Behavioral Sciences- Elsevier-vol. 1 ,pp. 401-408

[8] Eigbeonan, A (2013). Effective Constructivism for the Arch-Design Studio, International Journal of Architecture and Urban Development, Vol.3.No.4, pp. 5-12

[9] Jan Nijhuisa, Mien Segersb, C., Wim Gijselaers - (2008) - The extent of variability in learning strategies and students' perceptions of the learning environment Learning and Instruction - Elsevier-18 121-134.

[10] "Architecture: It's Elementary", AIA Michigan A Society of the American Institute of Architects Michigan Architectural Foundation- web based guide book for teachershttp://www.k5architecture.org/pdf/ga\%20-\%20Intro.pdf- last accessed 6-6-2013.

[11] Yearwood, J., \& Stranieri, A. (2007). Narrative-based Interactive Learning Environments from Modelling Reasoning. International Forum of Educational Technology \& Society (IFETS). Educational Technology \& Society, 10 (3), 192-208. 


\section{تثكيل ستوديو تصميم بنائي: محاكاة لخبرة المعماري الحياتية

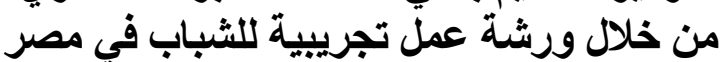

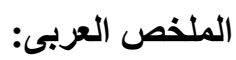

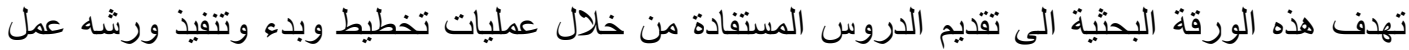

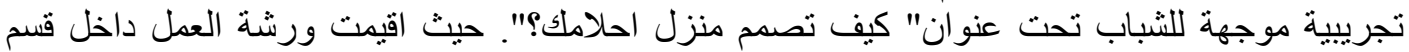

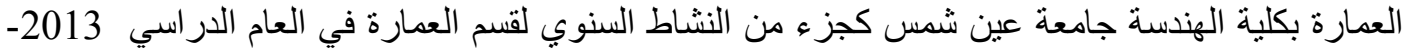

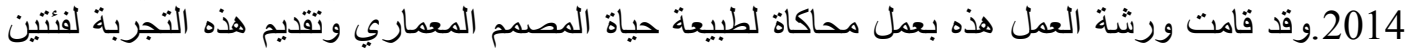

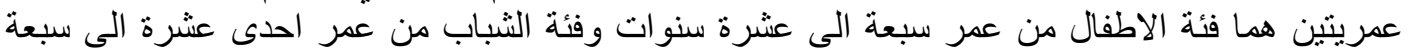

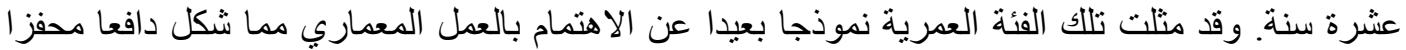

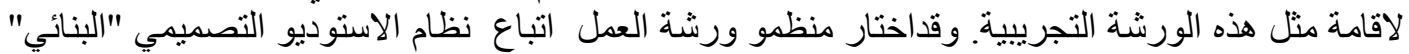

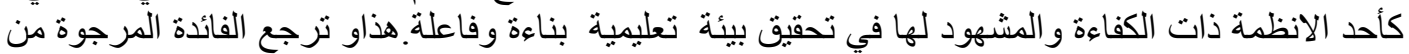

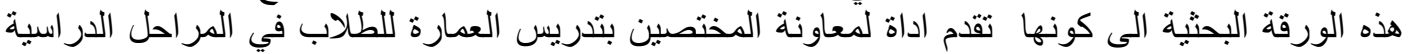

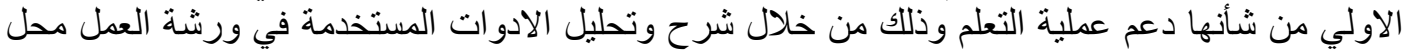
الدراسة والتي اثتتت فاعليتها في تحفيز الثباب على تعلم العمارة. 